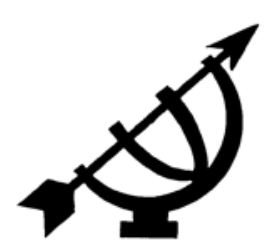

\title{
Project governance: selected South African government experiments
}

\author{
G. van der Waldt \\ Public Management and Governance \\ Potchefstroom Campus \\ North-West University \\ POTCHEFSTROOM \\ E-mail: Gerrit.vanderwaldt@nwu.ac.za
}

\section{Abstract \\ Project governance: selected South African government experiments}

Some form of accountability and power structure binds all organisations. Such structures are typically referred to as the "governance" structure of the organisation. In organisations that have relatively mature project applications and methodologies in place, governance mechanisms are established on more permanent bases. With its focus on performance, results and outcomes, project governance establishes decision-making structures, as well as accountability and responsibility mechanisms in public institutions to oversee projects.

As government institutions increasingly place emphasis on project applications for policy implementation and service delivery initiatives, mechanisms or structures should be established to facilitate clear interfaces between the permanent organisation and the temporary project organisation. Such mechanisms or structures should enhance the governance of projects, that is, the strategic alignment of projects, the decentralisation of decision-making powers, rapid resource allocation, and the participation of external stakeholders.

The purpose of this article is to explore the concept "project governance", and to highlight examples of project governance as applied in selected government departments in provincial and national spheres. This would enable the establishment of best practice examples and assist to develop benchmarks for effective project applications for service delivery improvement. 


\section{Opsomming}

\section{"Project governance": geselekteerde Suid-Afrikaanse proefnemings}

'n Bepaalde vorm van aanspreeklikheid en bevoegdheid bind alle organisasies. Daar word tipies na hierdie vorm as die "regering"- of "bes/uitnemingstruktuur" van die organisasie verwys.

In organisasies wat relatief gevestigde projektoepassings en projekmetodologieë in plek het, word regeerkundige meganismes op 'n meer permanente basis gevestig. Met die fokus op prestasie, resultate en uitkomste, vestig "project governance"meganismes besluitnemingstrukture sowel as aanspreeklikheiden verantwoordingdoeningsmeganismes in openbare instellings om projekte te moniteer.

Namate regeringsinstellings klem plaas op projektoepassings vir beleidsimplementering en diensleweringsinisiatiewe, behoort meganismes en strukture gevestig te word om duidelike koppelvlakke tussen die permanente organisasie en die tydelike projekorganisasie te bewerkstellig. Sodanige meganismes en strukture behoort die regeerbaarheid van projekte te verbeter, verwysend na die strategiese belyning van projekte, die desentralisasie van besluitnemingsbevoegdheid, snelle hulpbrontoedeling, en die deelname van eksterne aandeelhouers.

Die doel van die artikel is om die konsep "project governance" te verken en om voorbeelde van geselekteerde toepassings daarvan in openbare instellings op provinsiale en nasionale sfere uit te lig. Sodoende kan die beste praktykvoorbeelde ontleed word om die ontwikkeling van maatstawwe vir effektiewe projektoepassings vir diensleweringsverbetering te bevorder.

\section{Introduction}

Project management as a body of knowledge or discipline, with its own techniques, tools and vocabulary, has received attention since the late 1960s. However, the concept of project governance as an organisational phenomenon and management application only recently found its place in literature.

Some form of accountability and power structure binds all organisations. Such structures are typically referred to as the "governance" or decision structure of the organisation. In organisations that have relatively mature project applications and methodologies in place, governance mechanisms are established on more permanent bases. The trend towards oversight entities such as project offices and sound organisational practices, emphasising accountability, indi- 
cates the growing importance of governance. With its focus on performance, results, and outcomes, project governance establishes decision-making structures, as well as accountability and responsibility mechanisms in public institutions to oversee projects.

Typically, traditional, hierarchical, bureaucratic arrangements found in government institutions are not conducive to support projects, which require adaptability, decentralised decision-making powers, and delegated authority and responsibility. However, as government institutions increasingly place emphasis on project applications for public policy implementation and service delivery initiatives, mechanisms or structures should be established to facilitate clear interfaces between the permanent organisation and the temporary project organisation. Such mechanisms or structures should enhance the governance of projects, that is, the strategic alignment of projects, the decentralisation of decision-making powers, rapid resource allocation, and the participation of external stakeholders.

The purpose of this article is to explore the concept project governance, and to highlight examples of project governance as applied in selected government departments in provincial and national spheres. This would enable the establishment of best practice examples and assist to develop benchmarks for effective project applications for public service delivery improvement. Due to their autonomy in terms of the Constitution of the Republic of South Africa (South Africa, 1996), municipalities are excluded from the scope of this article.

\section{Project governance: the meaning, principles and elements}

A project can be defined as “... a collection of linked activities, carried out in an organised manner with a clearly defined start and finish point, to achieve some specific results that satisfy the needs of an organisation in a controlled and structured manner" (Young, 1996). In turn, Kerzner (2003) defines projects as any series of activities and tasks that have a specific objective to be completed within specification; have defined start and end dates; have funding limits; consume human and other resources; and are multi-functional. A project may, therefore, be viewed as the entire process that is required to produce a new product, service, process, system or other result within an established budget (Wilson-Murray, 1997). It involves a group of interrelated activities that are planned and then executed in a certain sequence to create a unique product or service 
within a specific timeframe, in order to achieve outcomes or benefits (Campbell, 2003:71).

The establishment of project management as a profession has been a major step in its global recognition and acceptance. In 1984, the Project Management Institute (PMI) administered the first Project Management Professional (PMP) certification examination, and in 1996, the Project Management Body of Knowledge (known as the PMBOK guide) was published.

The word government is from a Greek word, which means "to steer". In its broadest sense, a government is the democratically elected legislative body and the administrative and regulatory institutions it directs. It has the power to make and enforce laws for a certain territory and can be defined as the dominant decision-making arm of the state.

The Oxford Dictionary describes governance as "the act, manner or function of governing". Governing is defined in part as "regulating the proceedings of an entity". The concept has various applications in both public and private sector settings. It can be used in contexts such as corporate governance, international governance, national governance and local governance. In a private sector setting corporate governance refers to and includes mechanisms such as a board of directors. Since governance relates to accountabilities and responsibilities of management, it is the process of decision-making and the process by which decisions are implemented. In simple terms it thus refers to the rules, processes and behaviour that affect the way in which powers are exercised (Newman, 2001:34).

On a macro level governance or more correctly public governance typically refers to the interaction between a government and its citizens (Pollitt \& Bouckaert, 2000:23; Ingraham \& Lynn, 2004:34). It thus refers to all the processes and institutions through which the function of governing is carried out (Wamsley \& Wolf, 1996:77; Kooiman, 2003:21). Networked governance furthermore refers to the interdependence and interrelationship between various actors from the private sector, non-governmental and civil organisations, and the public sector to provide certain services and goods (Stoker, 2006: 41). Good governance as a concept is entrenched in governance discourse and has become part of the common shared principles and virtues of different countries in the world. It has attained universality as an indicator of adherence to democracy and rule of law (Denhardt \& Denhardt, 2003). 
On an institutional or departmental level the governance function includes the provision of strategic leadership, oversight, and accountability while ensuring that an organisation has clearly articulated their vision and mission which enhances the organisation's public image (Hobday, 2000:872; Turner \& Keegan, 2001:256).

Organisational governance describes how an organisation is directed and controlled. In particular, governance is concerned with the following (Lewis, 2003; Reid \& Bourn, 2004:235):

- Organisation - the organisational units and structures, groupings, and co-ordinating mechanisms (such as steering groups) established within the organisation and in partnership with external bodies, for the management of change.

- Management - the roles and responsibilities established to manage change and operational services, and the scope of the power and authority which they exercise.

- Policies - the frameworks and boundaries established for making decisions about investment in change, and the context and constraints within which decisions are taken.

Effective governance is crucial for the ongoing growth, sustainability and credibility of an organisation. To be successful, organisations should have a clear understanding of roles and authority of various levels of management (Thiry \& Deguire, 2007:651; Renz, 2007:233). Governance structures provide mechanisms for directing and controlling an organisation to ensure that all aspects of the organisation are effective within the requirements of various legislative frameworks.

The governance arrangements in organisations typically deal inter alia with the following issues (cf. Partington, 1996:15; Chien, 2004: 429; Bresnen et al., 2004:1538):

- The establishment and operation of best practice for the allocation and management of information, infrastructure and resources;

- the distribution of organisational responsibilities for managing projects and the relevant decision-making powers;

- the policies, procedures and practices implemented to ensure that the organisation derives maximum benefit from its strategyaligned projects; 
- requirements for the effectiveness, efficiency, confidentiality, integrity, availability, compliance and reliability of its information and information-based services; and

- the implementation of effective standards and controls for the design, development, implementation, maintenance, use, acquisition and management of project deliverables.

On a micro or project level, project governance extends the principle of governance into the management of individual projects. A project governance structure is different from an organisation structure in that it defines accountabilities and responsibilities for strategic decision-making per project. This can be particularly useful to project management processes such as change control and strategic (project) decision-making.

The concept project governance is seldom used in literature. Scholarly articles and text books rather simply refer to "project organisation", "enterprise project management", "managing organisations by projects", and "project-oriented organisations" to cover governance issues (cf. Meredith \& Mantel, 2000:139; Reid \& Bourn, 2004). The concept project management refers to the management of a project by making use of the nine knowledge areas of the Project Management Body of Knowledge (PMBOK) and does not make provision for authorisation, reporting arrangements, accountability, resource allocation, control and responsibility issues. The term governance in this context is used to encapsulate these issues. Under these and other concepts, issues such as project integration into existing organisational arrangements, specialisation, resource allocation, and the matrix form of organisation, are explored. Meredith and Mantel (2000:141) highlight especially two aspects that need to be considered when an organisation establishes a project. Firstly, a decision must be made on how to integrate the project with the organisation (system and process integration), and secondly, how to organise the project itself. Both of these decisions involve "governance".

Effective governance of projects ensures that an organisation's project portfolio is aligned to the organisation's objectives, that it is delivered efficiently and the project is sustainable. The project manager typically does not have the authority and/or seniority to ensure strategic alignment and compliance with processes. Governance of project management also supports the means by which the governing structure (i.e. steering committee or board), and other 
project stakeholders, are provided with timely, relevant and reliable information (Hobday, 2000:773; Reid \& Bourn, 2004).

The concept project governance originated mainly in the information technology sector to describe the authorative processes that need to be followed to ensure project success (Patel, 2007:1; Renz, 2007). Project governance can be regarded as a subset of project management methodology, which specifically describes decision-making structures and powers in projects. According to Renz (2007) it is a very recent development and includes issues such as authority over resource allocation, relationships between stakeholders, the flow of information, the review of issues, and the approval, steering and direction for the project at each stage of its life cycle.

\subsection{Project governance: elements, roles and principles}

Important specific elements of good project governance include a business plan stating the objectives of the project and specifying the in-scope and out-of-scope aspects as well as a mechanism to assess the compliance of the completed project to its original objectives (Turner \& Keegan, 2001:299). A further element includes the identification of all stakeholders with an interest in the project as well as an appropriate medium of communication to each. The appointment of a dedicated project manager with clear authority and responsibilities is a further governance element. The project manager with his/her team should also have a system of regular statusand progress-reporting to decision-makers (Artto, 2001:7). This is especially important to get timely approval for decisions, resource allocations, changes to the original plan and to resolve issues that arise during the project. Clear reporting lines are also necessary for quality and performance reviews of project deliverables (Reid \& Bourn, 2004).

Based on governance requirements and on the discipline of project management, the following principles have been identified for governance of project management. Applying these principles would help to avoid common causes of programme and project failure, such as those noted below (Andersen \& Jessen, 2002:459; Reid \& Bourn, 2004):

- The committee/board should have overall responsibility for the governance of projects.

- The roles, responsibilities and performance criteria for the governance of project management should be clearly defined. 
- Disciplined governance arrangements, supported by appropriate methods and controls should be applied throughout the project life cycle.

- All projects should have an approved plan containing authorisation or decision-points at which the schedule is reviewed and approved.

- Members of delegated authorisation bodies should have sufficient representation, competence, authority and resources to enable them to make appropriate decisions.

- There should be clearly defined criteria for reporting project status and for the escalation of risks and issues to the levels required by the organisation.

- Project stakeholders should be engaged at a level that commensurates with their importance to the organisation and in a manner that fosters trust.

One of the most difficult and most overlooked aspects of introducing project governance is the cultural implications (Cleland, 1988:52; Partington, 1996:15). Organisational culture must shift to be conducive to a project mindset and to provide project team members with the authority and assistance they need to adapt to the new ways of running projects. The culture must foster horizontal trust and cooperation among functional teams and vertical communication through the depths of the organisation. One of the most common complaints is the lack of ongoing support from executive management in upholding the project governance framework. Often, the biggest violators of the processes are the senior managers who established them in the first place (Cleland, 1988:53).

It is critical that authority, responsibility and accountability are vested in staff at the appropriate levels to enable them to perform their jobs. Authority or delegation should allow responsibility for a decision or supervision of an action to take place in a project. However, authority is frequently complemented by more important informal lines of communication and trust, shared experience, or discipline. One of the important aspects of responsibility for activities is the conferring of access to appropriate resources to "carry out" the responsibility. Responsibility entails accountability. Another aspect of responsibility is accepting the burden of the consequences. Links of accountability are tied to authority in the sense that those delegating responsibility are eventually accountable to others for results (Hobbs, 1993:83; Larson, 2004:49-51; Thiry \& Matthey, 2005). Typically project mana- 
gers are responsible for project deliverables, but do not have adequate authority to make resource allocation and utilisation (i.e. staff and budget) decisions. The governance structure should facilitate this process to ensure that project managers are supported in their responsibilities.

Arrangements for governance should form an integral part of the wider chain of command and decision-making structures within the organisation, management behaviour, and policies. Project governance will therefore need to be consistent with and aligned to the wider governance issues in the department.

Project governance could be influenced by a range of requirements and constraints arising from the following factors:

- external factors outside the organisation's direct control, such as those arising from the legal, fiscal, political, social, and technological environments within which the organisation operates;

- sector-specific factors, such as political directives within national or provincial government, strategic objectives, and service delivery targets and initiatives; and

- factors within the department such as its policies, culture, organisational structures, and level of project maturity.

To make a brief synopsis, project governance typically applies through the following components. These components do not significantly differ from established good project management elements, but make specific provision for decision-making/authority issues in projects:

\begin{tabular}{|c|c|}
\hline $\begin{array}{l}\text { Governance } \\
\text { component }\end{array}$ & Governance applies through ... \\
\hline $\begin{array}{l}\text { Management } \\
\text { (people) }\end{array}$ & $\begin{array}{l}\text { - who has/have a responsibility for implementing project- } \\
\text { related decisions } \\
\text { - } \text { defined responsibilities and accountabilities } \\
\text { - } \text { reporting arrangements } \\
\text { - } \text { disclosure and reporting }\end{array}$ \\
\hline $\begin{array}{l}\text { Organisational } \\
\text { arrangements } \\
\text { (structures) }\end{array}$ & $\begin{array}{l}\text { - terms of reference for structures created to govern a } \\
\text { project } \\
\text { - } \text { authority to make decisions } \\
\text { - } \quad \text { departmental interfaces (organogram) }\end{array}$ \\
\hline
\end{tabular}




\begin{tabular}{|c|c|}
\hline Methodology & 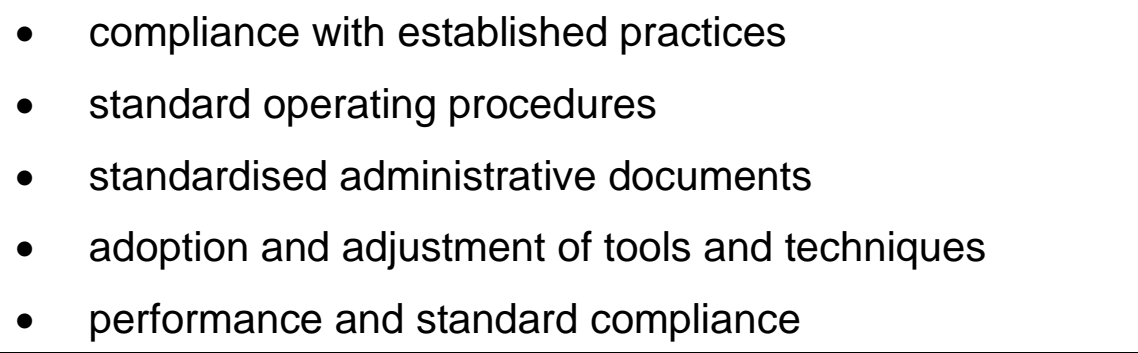 \\
\hline Policies & $\begin{array}{l}\text { - analyses of enabling and restraining aspects of policies } \\
\text { (enabling policies should support, promote and en- } \\
\text { courage effective project practices in the department) } \\
\text { - } \quad \text { allocation and utilisation of departmental resources (in- } \\
\text { cluding staff) } \\
\text { - compliance and analysis of metrics } \\
\text { - audits of projects }\end{array}$ \\
\hline Technology & $\begin{array}{l}\text { - IT interfaces (the use of management information sys- } \\
\text { tems of the department } \\
\text { - capture, store, process and disseminate project related } \\
\text { information to all role players and stakeholders }\end{array}$ \\
\hline
\end{tabular}

This concludes the brief synopsis of project governance elements, roles and principles. In the next section, specific focus will be placed on the need to establish innovative service delivery practices in the public services to accommodate project management principles.

\section{The need to establish innovative delivery approaches in the public service}

Innovation plays an important role in the place that project management now has in government institutions. However, there is a widely held assumption that the public sector is inherently less innovative than the private sector (cf. Moore, 1992:1050-1053; Peters, 1996; Pollitt \& Bouckaert, 2000:71). Imputed reasons include a lack of competition and incentives, a culture of risk aversion, political influences, and inflexible bureaucratic structures and processes. Effective government and public services depend on successful innovation - to develop better ways of meeting community needs, solving societal problems, and using scarce resources and technologies (DPSA, 2008). Innovation should be seen as a core activity to increase the responsiveness of services to societal needs and expectations. According to Contandriopoulos et al. (2004:627-655) debates about the form and nature of changes in the management of public structures have for some time now been articulated under the theme of governance. 
New Public Management (NPM) can be regarded as an umbrella label for a wide variety of administrative reforms with the common denominator of introducing market principles in the public sector and to allow for management models to replace political control as a coordinating mechanism in the public sector. Thus, it is a model of reform, which challenges pre-existing norms and ideals related to the public administration modus operandi (Clark \& Newman, 1997). It is, however, important to note that New Public Management is not synonymous with good governance (cf. Thomas \& Streib, 2003:8586). NPM refers to a specific model of administrative reform whereas governance refers to the process of governing and the mechanisms of public-private cooperation and interaction in that process.

In her comments, the former Minister of Public Service and Administration, Ms Fraser-Moleketi, in responding to the document of the United Nations Committee of Experts on Public Administration (CEPA) entitled "Revitalizing public administration: strategic directions for the future" (April 2005), raised the concern that one of the biggest strategic challenges public administration faces is how to reconcile the bureaucratic organisational form with its hierarchical characteristics and functional basis for structuring, with new organisational forms of networks. In this regard, Galbraith (1995:1) is of the opinion that public organisations are perceived as cumbersome bureaucratic structures. To adhere to the principles of project management, namely time, cost and quality, organisational design and arrangements should compliment this. Innovative design and arrangements are needed to become more project-based such as the introduction of flat, matrix structures (cf. Partington, 1996:14-16; Boyne, 2003:368).

Private entity managers generally have a fair degree of latitude in the management of people and resources, whereas public sector managers must adhere to strict statutory and regulatory guidelines as controlled by the Public Service Commission and the Constitution of the Republic of South Africa (South Africa, 1996). This makes it more difficult for project managers in government departments to obtain the necessary authority to deal with all project-related issues. Kerzner (1998:38) concurs with this argument and state that project management in a non-profit-driven organisation is generally more difficult for the following reasons:

- Projects may be few and executed on an ad hoc basis with large intervals between them. 
- Not all projects have the same project management requirements, and therefore they cannot be managed identically.

- Executives do not have sufficient time to manage projects themselves, yet refuse to delegate authority.

- Projects tend to be delayed because approvals most often follow the vertical chain of command. As a result, project work stays too long in functional departments.

- Only a portion of the organisation understands project management and sees the system in action, because staffing is on a local basis.

- There exists heavy dependence on subcontractors, consultant and outside agencies for project management expertise.

Kerzner (1998:38) warned that if these issues are not addressed, the result could be poorly defined responsibility areas within the organisation, slow service delivery implementation, a lack of a costtracking system for implementation, and poorly defined performance criteria. A managing-by-projects approach, which include governance mechanisms and sound project management practices, could go a long way to address these challenges.

This concludes the brief overview of the need for innovative practices in government. To analyse current realities as far as project governance in the South African public service is concerned, it is important in the next section, to compare it to the governance principles and the need for innovative practices.

\section{Typical project governance structures and mechanisms}

This section briefly outlines typical structures utilised globally to facilitate the governance of projects in the government. A typical challenge associated with the temporary nature of project applications in public institutions is the fact that institutional memory is lost when a project is completed and the team dissolved. In the process best practices and lessons learnt are not documented for future use. Meredith and Mantel (2000:147) call this challenge "projectitis", or the worry about life after the project ends. With a more permanent governance structure such as the Project Support Office, best practices are captured and earlier successes can be repeated in similar future projects. In line with the principles of the learning organization, forums should be created that allow people to 
discuss their experiences, successes, and problems. Such forums are powerful tools to spread project management lessons throughout the department (Bresnen et al., 2004:1537). Without the necessary authority, project managers and team members will not have the ability to act as change agents to ultimately alter policies and practices that impede the spread of project management or their successes in their departments. Magliolo (2008) refers to these small successes as the "guerrilla" principle of project management small successes (battles) which ultimately bring about significant changes (win a war). A permanent structure can uncover organisation-specific methodology and foster a project-based culture (Yeo, 1993:112; Gareis \& Huemann, 2000).

Below, a brief synopsis of the typical role and responsibilities of project governance structures and mechanisms is provided. The purpose of this synopsis is to compare international applications and best practices with those currently applied in the South African public service.

\subsection{Steering and/or advisory committees}

Some authors use the terms "steering committee" and "advisory committee" inter-changeably. Kerr (2005:132), however, distinguishes between the two and indicate that advisory committees are usually not formally responsible for the project. In some government projects advisory committees are useful mechanisms for identifying political risks and managing them through a process of co-option and negotiation.

The key element of steering, according to Kooiman (2003:117) is direction. Steering is arguably a form of "directed" governing. A project steering committee is generally the key governance structure, which is responsible for the issues associated with the project deliverables. This includes approving the budget, defining key deliverables, monitoring risks, quality and schedules, making resourcing decisions, and assessing requests for changes to the scope of the project. Reporting and decision-making lines should be kept as short as possible to facilitate rapid response as issues emerge (Denhardt \& Denhardt, 2003:231).

Membership of steering committees typically consists of the following:

- the head of the functional unit or directorate that will champion and finance the project; 
- managers of functional directorates who must support the project by making resources available;

- representatives from key stakeholders; and

- external, independent representatives, who may be specialist consultants, international and local experts.

Steering committee members should facilitate the participation of all stakeholders and align the project with the strategic objectives of the department. Members should also consider ideas and issues raised and foster positive communication outside of the steering committee regarding the project's progress and outcomes; review the progress of the project; and check adherence of project activities to standards of best practice (Elander, 2002:194; Kerr, 2005:133). The steering committee is further the key body responsible for reporting on project progress to the political head of the department (i.e. the Minister or MEC).

\subsection{Programme directors and project sponsors}

Projects are typically implemented on operational level and often project managers are on lower management level than functional heads from whom they must obtain resources. The "OPM3" model was especially established for this reason. OPM3 refers to Organisational Project Management on three levels, namely portfolio (strategic), programme (tactical) and project (operational) levels. This scenario may lead to a situation where project managers experience difficulty to obtain the necessary support from these managers. In such an environment it is crucial that a project sponsor and/or director be appointed, who can intervene on behalf of the team. A project sponsor is typically the head of the directorate in which the project will be implemented and he will "sponsor" (financially) the project.

Project sponsors and/or directors facilitate the integration of projects with existing organisational systems and arrangements (Turner \& Keegan, 2001:258). Project directors are responsible for top-end decisions regarding the projects. They may be the directors of directorates which will host the project.

Project directors and sponsors are typically responsible for an appropriate management framework and methodology for projects. They should obtain resources and expertise as required, for example, appointing consultants to support the project. Furthermore, they should facilitate client's input and control changes to the original 
scope of the project. They should also approve the project budget, including risk contingency reserves (Englund et al., 2003:112).

Another important function of project directors and/or sponsors is to establish formal reporting arrangements on project progress, and control mechanisms. They should assist project managers to resolve issues and establish a common approach with them to major issues that arise.

\subsection{Project management office, project support offices or project management units}

More recent organisational structures instituted to govern departmental projects are project support offices (PSOs), project management offices (PMOs), or project management units (PMUs).

A PMO, PSO or PMU often emerges as a mechanism to manage the project portfolio as an institution's project management maturity increases (Aubry et al., 2007:328). It may be situated at different levels in the institution and provide a variety of functions to a strategy or programme. According to Aubry et al. (2007:329) the PMO should no longer be considered an "isolated island" within an institution. They argue that it should be part of a network of complex relations that links strategy, projects and structures and is key to analyse the foundations of organisational project management.

A PMO provides the administrative and management support to projects within policy programmes. Its main function is to coordinate all projects with the strategic plan of the institution (cf. Renz, 2007). As such, the PMO is the champion for project success, but it needs to be continuously updated as new projects emerge in the institution. Project managers need to work with the PMO to ensure proper governance is in place. It should assist senior management with the prioritisation of projects, focus projects on strategic objectives, and assist in institutional resource allocation (Crawford, 2006:76).

The scope and authority of a PMO will vary depending on the organisational and management structure of the institution. The PMO's governance function plays an important role by providing decision support for project sponsors and stakeholders involved in the project. Documenting governance decisions and tracking action items for future governance sessions provide the administrative support needed for effective decision-making (Reid \& Bourn, 2004: 88-89). A dedicated PMO can provide the oversight and coordination to deliver projects on time and on budget by managing and 
reporting on schedule, risk, cost, quality, scope and resources across all projects. However, the balance between PMO process requirements and project delivery can be difficult to maintain. Both groups need to view each other as critical success factors to deliver the project for clients and need to communicate their needs to refine the process.

Government departments which utilise PMOs, experience the freedom for functional managers to concentrate on the operational aspects of the department, while the PMO takes care of the crossfunctional activities taking place with a number of teams brought together from various directorates on a temporary basis to deliver a product and/or service (Hobday, 2000:874).

\section{Project governance in the public service: selected experiments}

As explained, the application of project management methodology typically happens gradually or incrementally in public institutions. The reason why the word "experiment" is thus used in this article is to acknowledge the fact that government departments are not all on the same maturity level in terms of project applications. It is therefore necessary to uncover best practices in more mature departments in order for less mature departments to adopt best practices already uncovered by departments en route to higher levels of maturity.

Information contained in this section was obtained during the facilitation of project management training sessions to senior managers of provincial and national departments by the author over a period of two years. Only a brief snapshot of some governance examples is provided.

The Department of Minerals and Energy (DME) developed comprehensive guidelines, called "system development life cycle guidelines", released on 1 June 2006 for system development in the department. These guidelines clearly outline the roles and responsibilities of project managers, governance structures such as steering committees, business analysts, project sponsors, and project team members.

The Department of Home Affairs uses a number of projects to assist the transformation of the department. The minister chairs the department's steering committee and members include the director general, chief directors and representatives of a consultancy firm. 
The Public Administration Leadership and Management Academy (Palama) uses project reference groups, which comprise groups of stakeholders brought together to discuss and deal with operational issues of projects. Members may be part of the main project team, but may also be stakeholders from areas across Palama's services that will be impacted by the outcomes of the projects. Reference group members should bring operational issues from their functional areas to the reference group meetings and look for collaborative solutions to challenges.

The Department of Correctional Services (DCS) realised the benefits of project management for service delivery improvement and considered procedures and systems necessary to ensure that project management mechanisms utilised will be feasible and appropriate. Therefore DCS established a new Directorate: Project Management during 2007. This directorate is the centralised project management office as projects become a significant part of DCS's operations. The responsibilities of this directorate include the establishment of standardised guidelines, documentation and procedures, it furthermore acts as a centralised pool of project managers, it controls project schedules, costs, risks and communication, and uncover best practices for the department.

The Department of Public Service and Administration (DPSA) has relative mature project management applications in place. It has established programmes aimed at providing strategic support interventions and partnerships with government departments and provinces. For this purpose a Programme Management Office (PMO) was established in the office of the director general to oversee progress in the relevant programmes in the department. The PMO ties individual projects to a broad business goal, and monitors their interdependencies. Project management units were also implemented and the department appointed project directors and project sponsors for these units who report to the respective programme directors. DPSA also utilises technology to facilitate web-enabled project management to communicate and exchange information within the department. Tools such as templates, tables, diagrams and checklists are in the process of development to ensure uniformity in the department. They are also in the process of developing a project management information system that will be used to support all programmes and projects in the department.

The office of the premier, Limpopo Province, established a project management unit which liaises with a provincial intersectoral steering committee to coordinate and oversee cross-sectoral projects in 
the province. The intersectoral steering committee comprises of representatives from the office of the Premier, the South African Police Service, GCIS and the departments of Health, Home Affairs, and Agriculture. It provides overall leadership of projects from a provincial and national perspective to ensure that the interests of all members are met and those members ensure that their services are provided at the identified centres. The office of the Premier of the Northern Cape Province also established relative mature project governance mechanisms including a steering committee, and project sponsors (usually chief directors within the office). It further has a stakeholder committee comprising of representatives from provincial departments and local authorities, community representatives and civic organisations. This stakeholder committee's role is to act as a forum for informing stakeholders of progress, soliciting their comments and opinions, and liaising and encouraging practical buyin to a shared vision. The office of the premier also established a community advisory committee to liaise at a local level between service providers and the community and act as focus group for delivery improvement. They typically meet on a monthly basis to provide input to the respective project managers.

The Departments of Agriculture and Land Affairs are in the process of establishing a National Project Management Unit (NPMU) situated within the Ministry of Agriculture and Land Affairs as well as nine Provincial Project Management Units (PPMU) that will report to the national unit. The national PMU will ensure that adequate budgets, resources, systems and procedures are in place for PPMUs to meet their stated objectives. The NPMU will report directly to the minister and a ministerial committee, consisting of senior managers from both the Departments of Agriculture and Land Affairs.

In the Mpumalanga Province the Department of Local Government and Housing is busy with the establishment of a dedicated project management unit to drive the "Water for all flagship" project. The PMU will submit regular progress reports on its implementation to the Cabinet Executive Council through the Cabinet Governance and Criminal Justice Technical Cluster Committee in line with the accountability arrangements pertaining to all flagship projects.

The Office of the Public Service Commission (OPSC) currently is responsible to evaluate the overall performance of "one stop service centres" or multi-purpose community centres (called "Thusong" centres) in implementing procedures that are intended at providing regular and systematic consultation with clients at local level about their products and services. 
The Western Cape Education Department (WCED) directs the activities of the Khanya project through a governance structure consisting of a steering committee and an executive committee. The steering committee meets occasionally to determine Khanya policy and direction, and to readjust the vision of Khanya as and when determined by changing priorities. The other members of the committee are drawn from senior officials within the provincial administration of the Western Cape. The executive committee consists of various stakeholders within the WCED. It meets once a month and monitors project expenditure, project progress and gives direction on day-to-day implementation issues.

The Department of Trade and Industry's corporate and intellectual property registration office (CIPRO) utilises project review committees to facilitate partnerships between the department and business to keep abreast of progress made with joint projects. The project review committees function in conjunction with their project management office, which act as steering committees to foster partnerships with businesses. It is also in the process to institutionalise an active awareness programme to instil a project management culture. The department is also in the process of developing a programme management unit to facilitate integration among the different departmental interfaces to install a proper programme management culture and a managing-by-projects approach.

From these selected experiments it is clear that a "one size fits all" approach is not advisable. Project governance is about specific organisational functions and level of maturity. The more public institutions incorporate project applications in its strategic processes, the more the need for clear, well-established governance structures and mechanisms.

\section{Conclusion}

Project management practices evolve rapidly as public institutions realise the benefits associated with the application thereof to render services on time, within budget and according to community specifications. As a result, public institutions should adopt and adapt appropriate structures and processes to accommodate new demands placed on project-based service delivery.

It was the purpose of this article to explore the utilisation of governance structures and mechanisms utilised in government. It was established that the South African public service, in line with international trends, rapidly move towards maturity through the utilisation 
of governance structures associated with project applications. It is clear that most government departments at the national and provincial spheres already, to various degrees, utilise mechanisms and measures to effectively govern projects for service delivery improvement. The spread and growth of governance structures are a strong indicator that public institutions recognise the critical value of successful project management.

From the brief description of selected project governance experiments, it can be deduced that the South African public service in general, has firmly adopted project management methodology into its functions and practices. The project governance mechanisms that are utilised, conform significantly to the principles and best practice guidelines evident in literature. Relative mature practices are in place. Detailed case study research should be conducted to further uncover best practices associated with the establishment of project governance mechanisms and practices. Such knowledge and lessons learnt should be shared with other departments which are investigating the establishment of similar mechanisms and practices.

\section{List of references}

ANDERSEN, E.S. \& JESSEN, S.A. 2002. Project maturity in organisations. International journal of project management, 21:457-461.

ARTTO, K.A. 2001. Management of project-oriented organization - conceptual analysis. (In Artto, K.A. \& Aalto, M.M., eds. Project portfolio management: strategic management through projects. Helsinki: Project Management Association. p. 5-22.)

AUBRY, M., HOBBS, B. \& THUILLIER, D. 2007. A new framework for understanding organisational project management through the PMO. International journal of project management, 25:328-336.

BOYNE, G.A. 2003. Sources of public service improvement: a critical review and research agenda. Journal of public administration research and theory, 13(3):367-394.

BRESNEN, M., GOUSSEVSKAIA, A. \& SWAN, J. 2004. Embedding new management knowledge in project-based organisations. Organisation studies, 25(9):1535-1541.

CAMPBELL, G.M. 2003. Project management. 3rd ed. New York: Penguin.

CHIEN, M.H. 2004. An investigation of the relationship of organisational structure, employee's personality and organisational citizenship behaviours. The journal of American Academy of Business, 5(1):428-431.

CLARK, J. \& NEWMAN, J. 1997. The managerial state: power, politics and ideology in the remaking of social welfare. London: Sage.

CLELAND, D.I. 1988. The cultural ambience of project management - another look. Project management journal, 19(3):49-56.

CONTANDRIOPOULOS, D., DENIS, J., LANGLEY, A. \& VALETTE, A. 2004. Governance structures and political processes in a public system: lessons from Quebec. Public administration, 82(3):627-655. 
CRAWFORD, L. 2006. Developing organizational project management capability: theory and practice. Project manage journal, 37(3):74-86.

DENHARDT, J. \& DENHARDT, R. 2003. The new public service: steering, not DPSA serving. New York: Sharpe.

see SOUTH AFRICA. Department of Public Service and Administration

ELANDER, I. 2002. Partnerships and urban governance. UNESCO, 12:191204.

ENGLUND, R.L., GRAHAM, R.J. \& DINSMORE, P.C. 2003. Creating the project office: a manager's guide to leading organizational change. New York: Jossey-Bass.

GALBRAITH, J.R. 1995. Designing organizations: an executive briefing on strategy, structure and process. San Francisco: Jossey-Bass.

GAREIS, R. \& HUEMANN, M. 2000. Project management competences in the project-oriented organization. (In Turner, J.R. \& Simister, S.J., eds. The Gower handbook of project management. Gower: Aldershot. p. 182.)

HOBBS, B. 1993. Organizational choices for project management. (In Dinsmore, P.C. The handbook of project management. New York: Amacom. p. 163-167.)

HOBDAY, M. 2000. The project-based organisation: an ideal form for managing complex products and systems? Research policy, 29:871-893.

INGRAHAM, P.W. \& LYNN, L.E. 2004. The art of governance: analyzing management and administration. Washington: Georgetown.

KERR, G. 2005. Reflections on "The Steering Committee". American journal of evaluation, 26(1):132-134.

KERZNER, H. 1998. Project management: a systems approach to planning, scheduling, and controlling. 6th ed. New York: Van Nostrand Reinhold.

KERZNER, H. 2003. Project management: a system approach to planning, scheduling, and controlling. New Jersey: Wiley.

KOOIMAN, J. 2003. Governing as governance. London: Sage.

LARSON, E. 2004. Project management structures. (In Morris, P.W.G. \& Pinto, J.K. The Wiley guide to managing projects. New Jersey: Wiley.

LEWIS, J.P. 2003. Project leadership. New York: McGraw-Hill.

MAGLIOLO, J. 2008. The guerrilla principle: winning tactics for global project managers. Cape Town: Juta.

MEREDITH, J.R. \& MANTEL, S.J. 2000. Project management: a managerial approach. New York: Wiley.

MOORE, S.T. 1992. How useful is "bureaucracy? A review essay. Political research quarterly, 45:1049-1065.

NEWMAN, J. 2001. Modernising governance: new labour, policy and society. New York: Sage.

PARTINGTON, D. 1996. The project management of organisational change. International journal of project management, 14(1):13-21.

PATEL, D. 2007. Project governance: evolution, not revolution: projects@work. http://www.projectsatwork.com/content/articles/235972.cfm. Date of access: 30 Apr. 2009.

PETERS, B.G. 1996. The future of governance: four emerging models. Lawrence: Kansas University Press.

POLLITT, C. \& BOUCKAERT, G. 2000. Public management reform. Oxford: Oxford University Press. 
REID, B. \& BOURN, J. 2004. A guide to governance of project management: association for project management. Buckinghamshire: Wycombe.

RENZ, P.S. 2007. Project governance: implementing corporate governance and business ethics in non-profit organizations. Heidelberg: Physica.

SOUTH AFRICA. 1996. The Constitution of the Republic of South Africa: Act 108 of 1996. Pretoria. Government Printer.

SOUTH AFRICA. Department of Public Service and Administration. 2008. The Centre of Public Service and Innovation. http://www.cpsi.co.za/cpsi1/ home.jsp. Date of access: 10 Sept. 2008.

STOKER, G. 2006. Public value management: a new narrative for networked governance? The American review of public administration, 36(4):41-57.

THIRY, M. \& DEGUIRE, M. 2007. Recent developments in project-based organisations. International journal of project management, 25(7):649-658.

THIRY, M. \& MATTHEY, A. 2005. Delivering business benefits through projects, programs, portfolios and PMOs. Proceedings of PMI Global Congress, Singapore.

THOMAS, J.C. \& STREIB, G. 2003. The new face of government: citizeninitiated contacts in the era of e-government. Journal of public administration research and theory, 13(1):83-102.

TURNER, J.R. \& KEEGAN, A. 2001. Mechanisms of governance in the projectbased organization: roles of the broker and steward. European management journal, 19(3):254-267.

WAMSLEY, G. \& WOLF, J., eds. 1996. Refounding democratic public administration: modern paradoxes, postmodern challenges. Thousand Oaks: Sage.

WILSON-MURRAY, R. 1997. Managing projects: a new approach. Brisbane: Wiley.

YEO, K.T. 1993. Systems think and project management: time to reunite. International journal of project management, 11(2):111-117.

YOUNG, T.L. 1996. The handbook of project management: a practical guide to effective policies and procedures. London: Page.

\section{Key concepts:}

governance projects

project governance

project governance mechanisms

project management

\section{Kernbegrippe:}

"project governance"

"project governance"-meganismes

projekbestuur

regeringsprojekte 